\title{
鉄筋コンクリート部材の鋼材腐食に及ぼす 曲げひび割れの内部構造の影響
}

\author{
林 和彦 1 -椿 龍哉 2 - 細田 暁 3 \\ 1正会員 横浜国立大学特別研究教員 大学院工学研究院（干240-8501 神奈川県横浜市保土ヶ谷区常盤台79-5） \\ E-mail:hayashi@ynu.ac.jp \\ 2正会員 横浜国立大学教授 大学院工学研究院（†240-8501 神奈川県横浜市保土ヶ谷区常盤台79-5) \\ E-mail:tsubaki@ynu.ac.jp \\ 3 正会員 横浜国立大学准教授 大学院環境情報研究院（=240-8501 神奈川県横浜市保土ヶ谷区常盤台79-5） \\ E-mail:concrete@ynu.ac.jp
}

\begin{abstract}
曲げひび割れは鉄筋コンクリート部材のかぶりの物質移動に悪影響を及ぼす。しかし，表面ひび割れ幅 以外の鋼材近傍のひび割れ幅や付着剥離部分などの曲げひび割れの内部構造については十分に把握されて おらず，物質移動や鋼材腐食に及ぼす影響も明らかにされていない。また，耐久性の向上を目的としたか ぶりの増加がひび割れの内部構造に与える影響も不明確な点が多い.

本研究では, 繰返し荷重とかぶり厚さに着目し, 腐食促進実験およびひび割れ損傷の可視化手法を用い, 曲げひび割れの内部構造の変化が鋼材腐食へ及ぼす影響を調べた。 その結果, 荷重の繰返し作用によりひ び割れ内部の幅と付着剥離長さが増加し鋼材腐食の開始が早まること，かぶりの増加により内部ひび割れ の発生状況が変わり鋼材近傍のひび割れ幅が増加する場合があることがわかった。
\end{abstract}

Key Words : flexural crack, steel corrosion, cyclic load, visualization of crack, internal crack, bond degradation, chloride ion

\section{1. はじめに}

鉄筋コンクリート部材の中性化や塩害による鋼材腐食 に対する耐久性を考えるにあたり，現在では，かぶりの 物質移動抵抗性を高めることが求められている. コンク

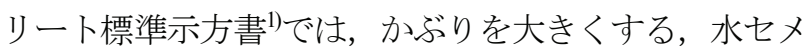
ント比（以下，W/C）を低くしコンクリートを緻密にす る，コンクリート表面における曲げひび割れ幅（以下， 表面ひび割れ幅）を制限するなどの方策が組み合わせて 用いられている.

曲げひび割れ（以下，ひび割れ）と鋼材腐食の関係性 を導くためにこれまで数多くの暴露実験が行われている その結果，ばらつきが大きく統一的な見解は得られてい ないものの，概ね短期的には腐食の発生時期に関係があ るが，長期的にはひび割れと腐食には関係がない，と整 理されている2). 腐食と関係がない理由には電気化学的 メカニズムの説明の他に，ひび割れを表面ひび割れ幅の みで代表させていることが挙げられている．コンクリー ト内部の鋼材表面に近づくにつれて，ひび割れのその位 置での幅（以下，ひび割れ内部の幅）は小さくなるひ び割れを物質の通り道と考えると，一番大きな表面にお
ける幅よりも，一番小さな鋼材近傍での幅やかぶり全体 の平均的な幅の方が，物質移動に対して影響を与えやす いと考えることもできる．また，ひび割れと鋼材が交差 する位置で生じるコンクリートの付着剥離部分について 着目し，付着剥離長さを鋼材の腐食現象と関連付けて考 察している例もある3).

一般にはかぶりが同じ程度であれば，表面ひび割れ幅 はそのひび割れ内部の幅や付着剥離の程度にも相関があ り，現状の設計式においても表面ひび割れ幅を考慮して おけば陰な形として両者の影響を考慮していると捉える こともできる. しかし，一時的な大きな荷重により一度 発生したひび割れは，除荷されても完全には回復できな いため, 供用時の表面ひび割れ幅が小さくても, 内部の 損傷状態がどのようになっているのかは明らかではない. かぶりが大きくなると表面ひび割れ幅はかぶりに比例 して大きくなることが一般に知られているが，かぶりが ある值を超えると鋼材近傍のひび割れ幅が急激に増加す ることも一部で報告されている4).ただ，かぶりの大き さを変化させて鋼材近傍のひび割れ幅を測定している例 は少なく4),5), 統一的な見解が得られているわけではない. 以上のように，ひび割れが鋼材腐食に及ぼす影響につ 


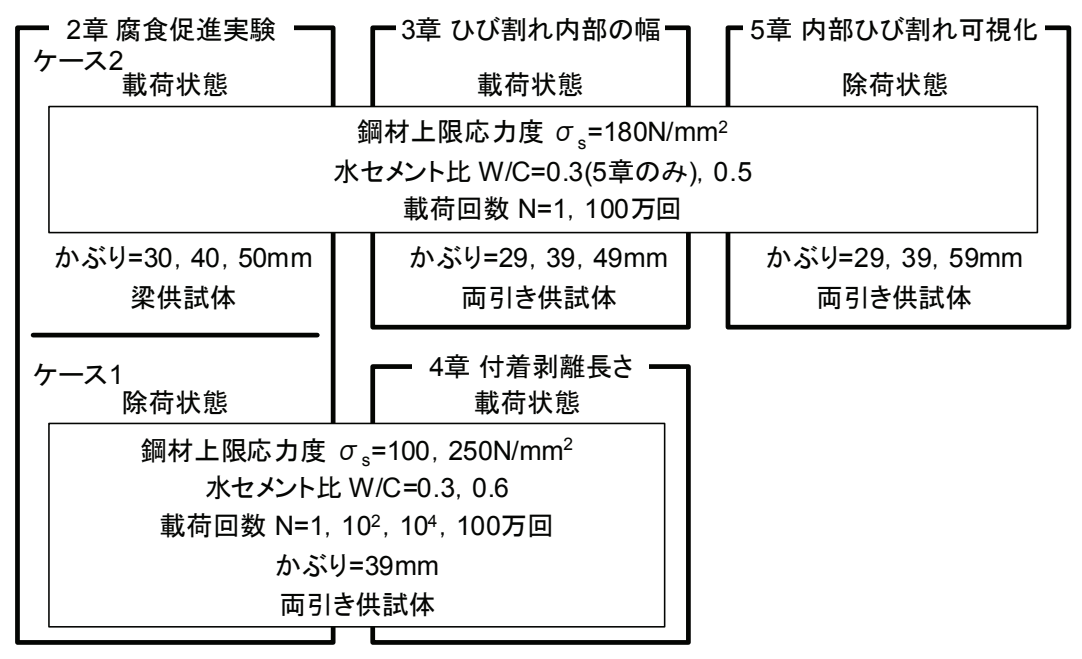

図-1 各実験の連関図と実験条件

表-1 実験条件の一覧

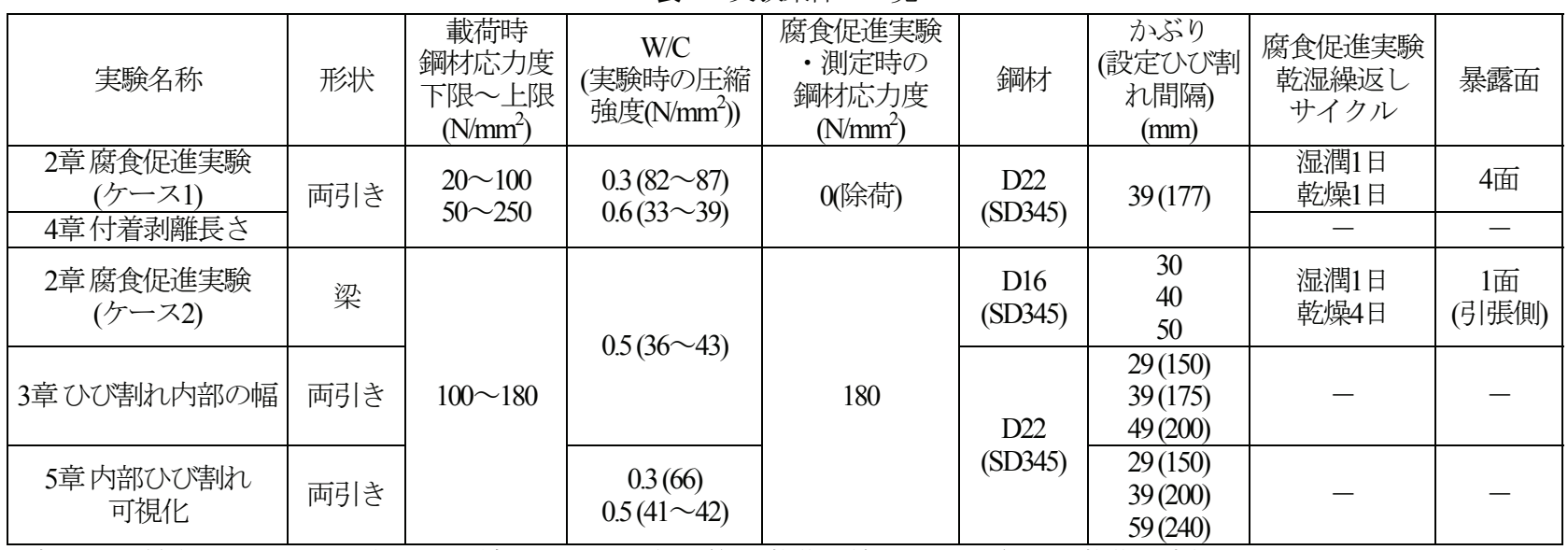

粗骨材の最大寸法 : $20 \mathrm{~mm}$ ，打設後封緘約 3 日間の後気中養生(載荷材齢7 28日), 繰返し載荷周波数 : $8 \sim 15 \mathrm{~Hz}$

腐食促進実験ケース2のみ鋼材の黒皮を除去

いて未だ不明確な点が多い. そこで本研究では，かぶり や載荷回数の影響に着目し，物質移動に対して直接的に 影響を与えるひび割れの内部構造（表面および内部での ひび割れ幅, 付着剥離, 内部ひび割れ5) が鋼材腐食に 与える影響について基礎的な検討を行うこととした。

本論文では図-1に示すとおり，2章で腐食促進実験の 結果を示し，その結果を説明するために，3，4，5章に おいてひび割れ内部の幅, 付着剥離の長さ, 内部ひび割 れの幅と長さを測定した．個々の詳しい内容については, 既報け11)に示している.

ここでは，曲げひび割れなどの鋼材を貫通するひび割 れ（以後，断りがなければ単に「ひび割れ」とし，「内 部ひび割れ」と対比させる時には「主ひび割れ」と記述 する）における物質移動が律速となる状態を主として対 象としている. その理由は，コンクリート標準示方書1) では腐食発生を1つの限界状態としており, 既往の暴露 実験 ${ }^{2)}$ では腐食発生時期はひび割れも1つの支配要因とな るからである.よって，ひび割れのない部分のかぶりの 物質移動が律速となるような比較的長期的な状態は本研
究では扱っていない.

\section{2. ひび割れと塩化物イオンによる鋼材腐食発生}

\section{(1) 実験概要}

ひび割れを有する鉄筋コンクリート供試体を作製し， 繰返し載荷が鋼材腐食に及ぼす影響について実験的検討 を行った ${ }^{0,7)}$ ，実験条件を表-1，供試体形状を図-2に示す. 周辺の付着を乱さないよう鋼材にはひずみゲージを貼付 せず, 所定の鋼材応力度となるようにコンクリートの引 張を無視した弾性計算で求めた荷重を与えた。設定した ひび割れ間隔は，予備検討によりその断面寸法において ひび割れ定常状態となる間隔であり，その位置でひび割 れを発生させるため, ダイヤモンドカッターにより幅 $3 \mathrm{~mm}$ ，深さ5mmの切欠きを設けた.

ケース1では，除荷した残留ひび割れの状態で腐食促 進実験を行った。形状は両引き供試体であり，W/Cを2 水準 $(0.3,0.6)$, 鋼材応力度を 2 水準（鋼材の上限応力 


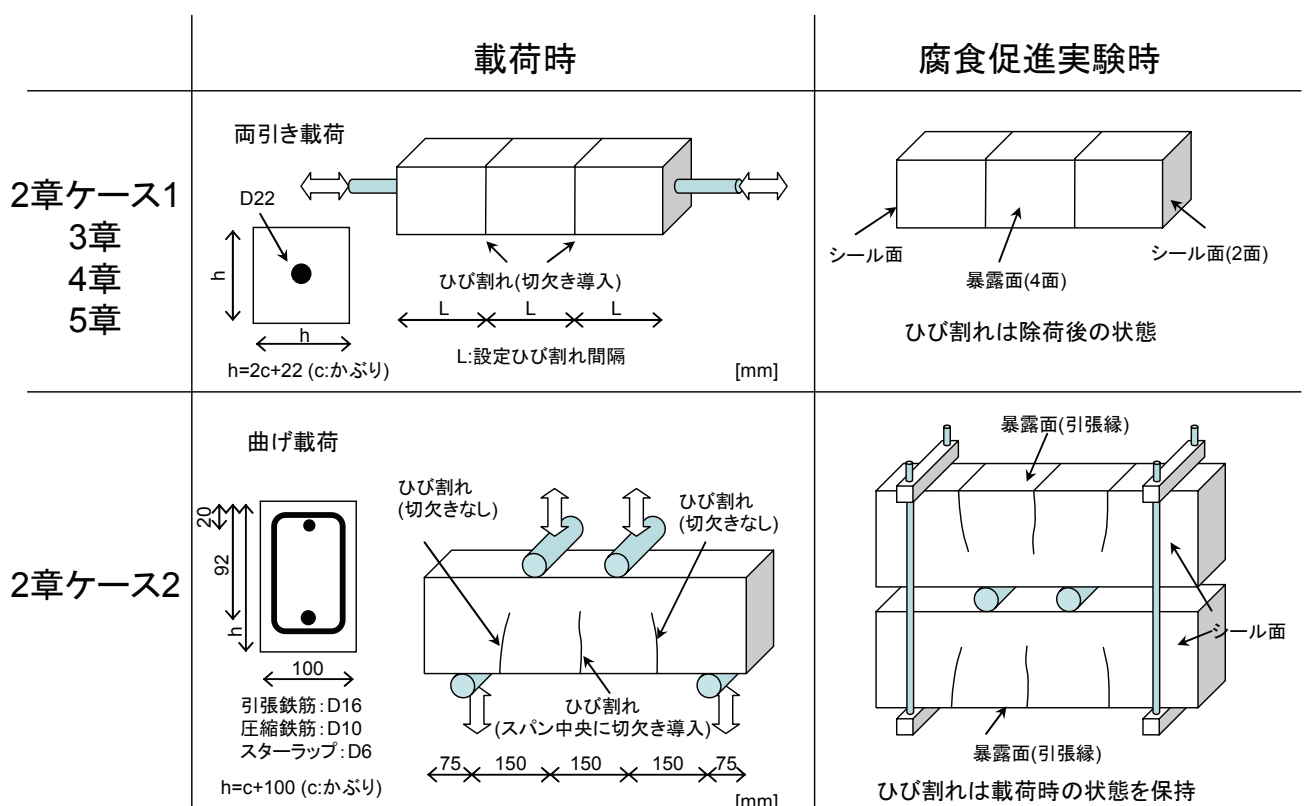

図-2 供試体形状

度が100, $250 \mathrm{~N} / \mathrm{mm}^{2}$ ) とした. 所定の回数の載荷後に除 荷し，暴露面以外をエポキシ樹脂で覆い，腐食促進実験 に供した。腐食促進実験では, $40^{\circ} \mathrm{C}$ 海水の乾湿繰返し （湿潤1日，乾燥1日）を与えた。

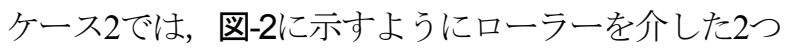
の梁供試体を載荷フレームで固定し, ナットの締め具合 を調整して載荷時と同じ幅のひび割れが開いた状態を再 現させ保持しながら腐食促進実験を行った。ケース1で は再現できていなかった実構造物における死荷重により ひび割れが開いている状態を再現するためである. かぶ りの大きさの違いを把握するために，かぶりを 3 水準

（30，40，50mm）に設定した. ケース $1 の$ 実験条件に比 べ，荷重を保持するために両引き供試体から梁供試体一 と形状を変更し，同時に乾湿繰返しのサイクル，鋼材応 力度，W/C，鋼材の黒皮除去の有無，の点を変更してい る. 乾湿繰返しのサイクルについては, ケース 1 の畭燥1 日ではひび割れ内部まで完全に乾燥できなかったため, 湿潤1日，乾燥4日と設定した. 載荷応力度には鉄道構造 物の設計計算例 12 ${ }^{{ }^{-}}{ }^{13)}$ の床版の許容応力度を参考にして, 上限応力度（活 荷重載荷時）を $180 \mathrm{~N} / \mathrm{mm}^{2}$, 下限応力度（死荷重載荷 時）を $100 \mathrm{~N} / \mathrm{mm}^{2}$ に設定した。腐食促進実験時に保持し た鋼材応力度は，ひび割れ開口の影響を明確に出すこと を目的として, 死荷重を想定した下限忘力度ではなく活 荷重を想定した上限応力度とした。

ケース1，2ともに，それぞれ同一条件の供試体で，載 荷回数を变化させ相対比較を行った．設定した載荷回数 は，ケース1の両引き供試体では繰返しの影響を詳細に 観察するために，0，1，10２１0 $0^{4} ， 100$ 万回とし，ケース 2の梁供試体では1回および100万回とした．鋼材腐食の
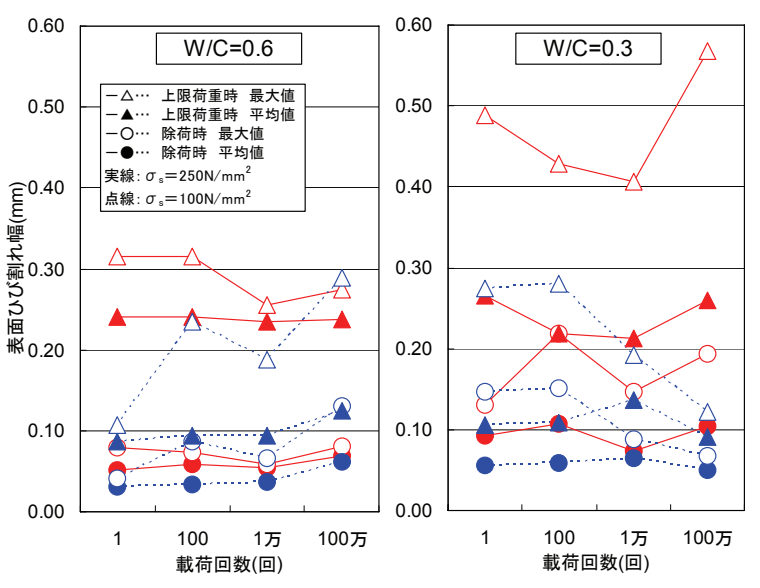

図-3 表面のひび割れ幅（ケース1）

判定には，自然電位測定 ${ }^{14)}$ 用いた. 所定の期間が終了 後, 一部の供試体からは鋼材を取り出し, 腐食の有無や 程度を調べた。

\section{(2) 除荷後の腐食促進実駼結果（ケース1両引き供試体）}

両引き載荷の結果, 切欠きを入れてひび割れを誘発し た部分でひび割れが生じた. 各供試体の最大載荷回数時 における上限荷重時の表面ひび割れ幅，除荷時の表面ひ び割れ幅（乾湿繰返し時のひび割れ幅と同じと考える） についてまとめたものが図-3である，上限荷重時の表面 ひび割れ幅は供試体毎のばらつきが大きいものの，腐食 促進実験時に相当寸る除荷後の表面ひび割れ幅は，ほぼ 一定となっている.

まず，腐食促進実験の結果，腐食の程度が大きかった $\mathrm{W} / \mathrm{C}=0.6$, 上限応力度 $250 \mathrm{~N} / \mathrm{mm}^{2}$ の結果を示す. 図-4は載 荷回数 100 万回のものであり, 横軸が供試体の軸方向を 




図-4 自然電位の分布 (ケース 1$)$

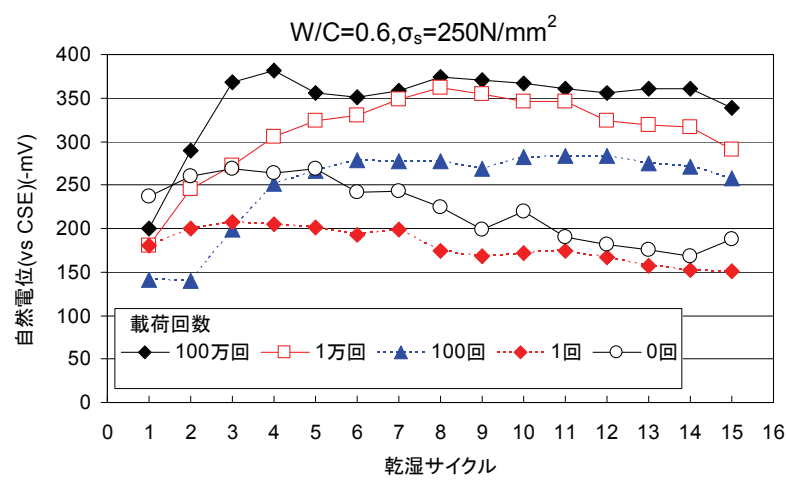

図-5 自然電位の経時変化（ケース 1$)$



図-6 鋼材の腐食状況

表し，3等分の位置での縦線はひび割れ発生位置を表す。 乾湿サイクル数の増加に伴い，自然電位が卑に変化する 様子がわかり，特にひび割れ部分で突出している，後の 鋼材取出しによる腐食調査結果により，ひび割れ近傍の み鋼材が腐食していたが，ひび割れ以外の部分もつられ て卑になっているのは，ひび割れ部の自然電位低下が周 囲にも影響を及ぼしているためである.

図-5は，各供試体の供試体全長の自然電位の平均值の 時間推移を示す. 載荷回数 100 万回の供試体では 2 サイク ルで，104回では7サイクルでASTMの腐食判定基準 ${ }^{15}$ と なる-350mVに達し, その後も卑な状態で一定になって いるのに対し, 載荷回数が1回のものは-350mVに達して おらずその後も自然電位の変化がない，なお，無載荷で
ひび割れの発生していない0回の供試体では，初期にお いて-250mV程度になっているが，その後貴に推移し1回 載荷と同程度で推移している. 途中の回数である $10^{2}$ 回 供試体については，1回と104回の中間を推移し最終的に は-350mVに達していない。これらの結果より, 載荷回 数が増えるにつれて, 自然電位が卑になり腐食判定基準 值に到達するサイクル数が早まり, 載荷回数が少ないと その值に到達していないことがわかる.

15サイクル終了後, 一部の供試体から鋼材を取り出す と，図-6に丸印で示したように，100万回ではひび割れ 部において腐食が開始しており，1回，0回は全く腐食が 見られず，自然電位の測定結果と対応していた.

鋼材応力度を下げた, $\mathrm{W} / \mathrm{C}=0.6$, 上限応力度 $100 \mathrm{~N} / \mathrm{mm}^{2}$ の供試体では，概ね同様の傾向が見られたが，最終的に 腐食をしていなかった0回のものを除くと, 自然電位が 卑に変化した順番は 100 万回，102回の順となり，104回と 1回では自然電位が卑にならなかった．載荷回数に完全 に対応した傾向は見られなかったものの，概孜載荷回数 が多くなるにつれて鋼材腐食の時期が早まっている.

$\mathrm{W} / \mathrm{C}=0.3$ では，上限応力度 $250 \mathrm{~N} / \mathrm{mm}^{2}, 100$ 万回載荷の 1 供試体だけ-350mVよりも卑となったが，それ以外の回 数および, 上限応力度 $100 \mathrm{~N} / \mathrm{mm}^{2}$ の全ての回数は, 自然 電位に変化が生じなかった. W/C=0.6に比べて自然電位 の変化が顕著でなかった理由としては, 実験期間が短く 差が現れにくかった, 載荷回数の影響を受けるW/Cの範 囲が存在する，という2つが考えられる.

以上より，暴露時の表面ひび割れ幅に変化がなくても， 1回と 100 万回とを比較すると載荷回数が増えると自然電 位が卑になりや寸く, その程度は鋼材の応力度が大きい ほど，W/Cが高いほど顕著であるという傾向が見える.

\section{(3) 載荷中の腐食促進実験結果（ケース2梁供試体）}

梁供試体のひび割れ幅の測定の都合上，ひび割れ位置 を特定するためにスパン $450 \mathrm{~mm} の$ 中央に1箇所の切欠き を設けた，かぶり $30 \mathrm{~mm} と 40 \mathrm{~mm}$ の供試体では，載荷によ るひび割れは切欠き位置およびその両側の計3本発生し たものの, かぶり50mmでは切久き位置のみにひび割れ が発生した. よってケース2の梁供試体の結果は，かぶ り50mmのみひび割れ間隔が2倍以上に大きくなっている ことに注意が必要である.

スパン中央のひび割れにおける載荷時の表面ひび割れ 幅を表-2に示す、ひび割れの幾何学的形状の変化および 曲げによる曲率の影響により, かぶりの増加に応じて表

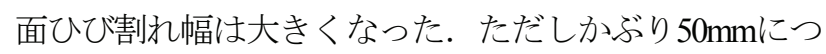
いては前述のとおりひび割れ間隔が2倍程度に大きくな った影響が大きいと考えている，それぞれ，載荷回数に よる表面ひび割れ幅の変化はほとんど見られなかった。 
表-2 曲げ載荷時の表面ひび割れ幅（最大荷重時）

\begin{tabular}{|c|c|c|}
\hline かぶり $(\mathrm{mm})$ & 1 回 $(\mathrm{mm})$ & 100 万回 $(\mathrm{mm})$ \\
\hline 30 & 0.170 & 0.157 \\
\hline 40 & 0.214 & 0.229 \\
\hline 50 & 0.375 & $-{ }^{* 1}$ \\
\hline
\end{tabular}

*1 変位計の不備で未測定. 供試体側面で直接幅の測定を 行い，1回と100万回供試体でほとんど差がなかったこと を確認した.

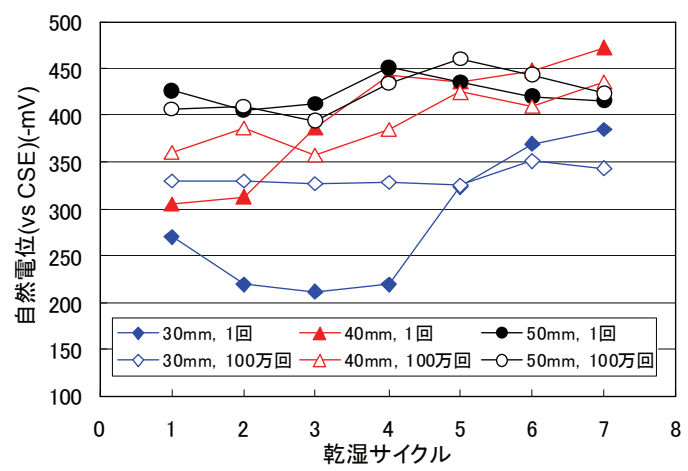

図-7 自然電位の経時変化 (ケース 2$)$

繰返し載荷後に一度除荷して腐食促進実験用の載荷フレ 一ムにより再載荷を行っているが，腐食促進実験時の表 面ひび割れ幅は概ね繰返し載荷時のひび割れ幅を再現で きている.

図-7に腐食促進実験時の全供試体の自然電位の推移を

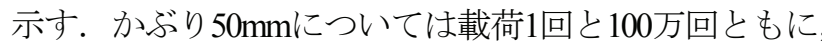
乾湿1サイクル終了時点で-350mVを下回り腐食が発生し たと推定でき，載荷回数による腐食開始サイクルの差が 見られなかった.この理由として，他のかぶりと比べて ひび割れ間隔が大きくなったためひび割れ幅自体が過度 に大きくなったことと，ケース2の梁供試体のみ鋼材表 面の黒皮を除去しケース1の両引き供試体に比べて全体 的に早期に腐食しやすくなったこと，の2つの理由を考 えている.

かぶり 40mmでは自然電位が-350mVを下回ったのが, 載荷 100 万回で乾湿1サイクル，載荷1回で乾湿3サイクル であった。かぶり 30mmでは-350mVに達したのは共に6 サイクルであるが，100万回のみ1サイクル目において既 に-350mV付近には達していた.

かぶりの違いによる比較を行うと，かぶり50mmはひ び割れ間隔が他と比べて大きく異なるために除外して考 えると，30mmと40mmでは，40mmの方が早期に自然電 位が卑になった。

\section{(4) 腐食促進実験のまとめ}

自然電位の測定值はコンクリートの抵抗值の影響を受 けるため，同じかぶりでの相対比較を行うと，ケース 1 , 2ともに腐食促進実験の期間が1ヶ月程度と短期間ではあ るが，その範囲においては，載荷回数の増加にしたがい

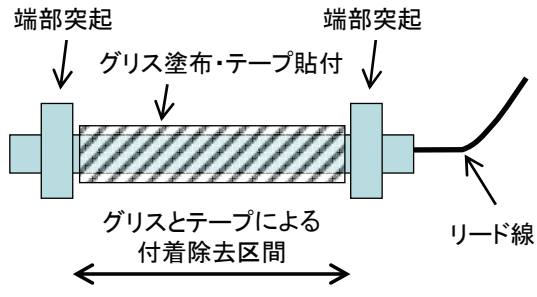

図-8 簡易変位計の構造

自然電位が腐食判定基準值に達するサイクルが短くなる 傾向が見られた。

なお，ケース1，2ともに実験期間は約1ケ月と同じで あるが，最終的な腐食の有無の差が生じた理由としては， 設定した乾湿繰返しの組合せ日数の違いが大きな影響を 及ぼしたためと考えている，ケース1では乾燥期間が1日 と短かったため，十分に乾燥が完了しないまま次の湿潤 サイクルに移ったため腐食に必要な酸素の供給が少なか ったものと推察している.

かぶりの大きさが腐食に与える影響については，かぶ り $50 \mathrm{~mm}$ の結果は除外しなければならないため，今回は かぶり $30 \mathrm{~mm}$ と $40 \mathrm{~mm}$ の比較のみを行うと，40mmの方が 自然電位が腐食判定基準值に達するサイクルが短くなっ た. しかし鋼材の応力度を一定とした実験条件のため, 生じた表面ひび割れ幅についてはかぶり40mmの方が 30mmに比べて大きいため，ここではかぶりの大きさの みと腐食との関係を論ずることはできない.

\section{3. ひび割れ内部の幅}

\section{(1) 実験概要}

2章の腐食促進実験で対象としたひび割れを介しての 物質移動を把握するには，物質移動の経路となるコンク リート内部でのひび割れの状態を直接把握することが有 効であると考える．2章ケース2の梁供試体の腐食促進実 験中の載荷条件（ひび割れが載荷状態で開口）に対応す る供試体を，形状が異なるものの両引き供試体により再 現させ，次の2つの方法によりひび割れ内部の幅の測定 を行った.

1つ目の方法では，既往の樹脂注入方法(4), を参考に低 粘性のエポキシ樹脂をひび割れ内部に注入し，エポキシ 樹脂硬化後にひび割れを含む部分のコンクリートの切断 と研磨を行い，マイクロスコープで直接ひび割れ内部の 幅を測定した7)。この方法は破壊測定であるため，繰返 し載荷の途中経過を把握するために，同時に $2 つ$ 目の方 法として簡易変位計を鋼材近傍のコンクリートに埋め込 んでその部位でのひび割れの幅を測定した。図-8に示す 簡易変位計は，両端部に突起のついたモールドゲージの 


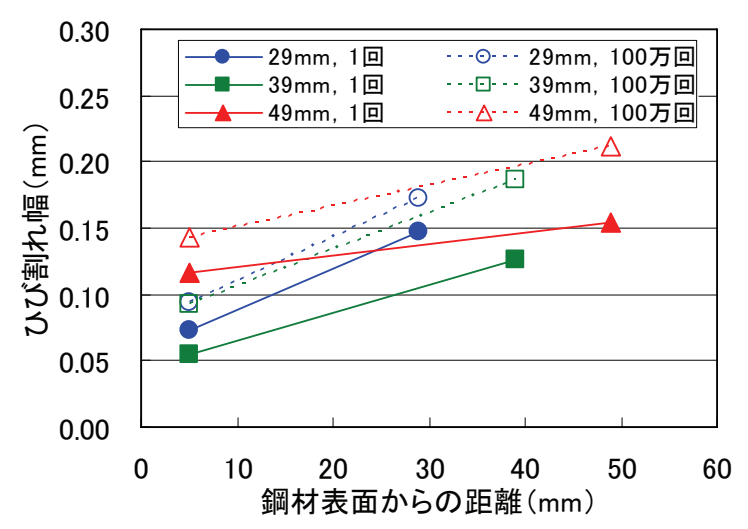

図-9 変位計測定によるひび割れ幅

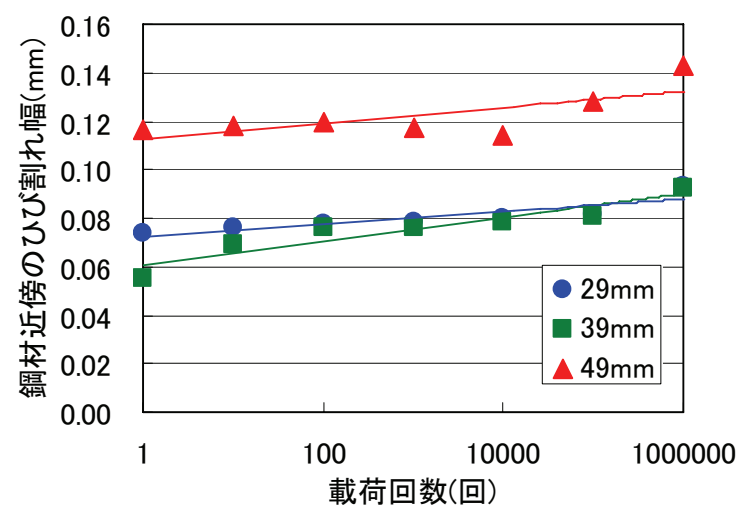

図-10 変位計測定による鋼材近傍のひび割れ幅

中間部にグリスを塗布しテープを巻くことによりコンク リートとの付着を取り除いたもので，突起間の検長 60mmの相対変位が測定できる，表面では1本のひび割れ も内部では複数に分岐している場合がある8)が，簡易変 位計により測定された変位を変位計を跨ぐ個々のひび割 れの幅の総和とみなした。

実験条件を表-1，供試体形状を図-2に示寸，2章ケー ス2の梁供試体の腐食促進実験とは鋼材径と供試体形状 が異なるものの，かぶりはほぼ同等になるような3水準

（29，39，49mm）を設定した．定常状態のひび割れ間 隔はかぶりの大きさに比例する10ため，いくつか供試体 長さを変化させた予備実験の検討から，完全に比例では ないもののかぶりの増加に応じてひび割れ間隔を増加さ せた. よって，比較する2章ケース2の梁供試体のかぶり 50mmの供試体は前述のとおり他のかぶりに比べてひび 割れ間隔が過大になりひび割れ幅が大きくなってしまっ たものの，対応させた3章のかぶり49mmの両引き供試体 は他のかぶりに比べてひび割れ間隔が過大になっている ことはない，なお，かぶり49mmの100万回載荷供試体で は，測定の都合上樹脂注入による測定結果が得られてい ない。

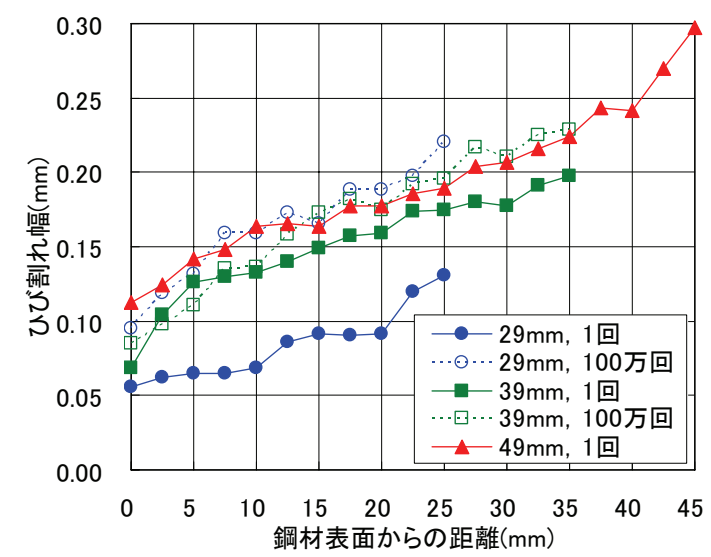

図-11 樹脂注入測定によるひび割れ内部の幅

\section{(2)ひび割れ内部の幅の測定結果}

コンクリート中の鋼材近傍に設置した簡易変位計およ び表面に貼り付けたパイ型変位計により非破壊で測定し たひび割れ幅の測定結果を図-9に示寸。これらは最終的 に100万回載荷を行った供試体の值である．載荷1回時の みを比較すると，表面ひび割れ幅はかぶりの違いによっ て大きな変化はない，一方，鋼材近傍のひび割れ幅はか ぶり $29 \mathrm{~mm}$ と $39 \mathrm{~mm}$ では $0.07 \mathrm{~mm}$ 程度で大きな差は無いもの

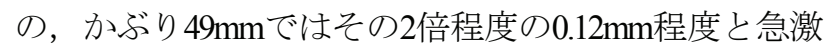
に大きくなった．また，載荷の繰返しにより，表面ひび 割れ幅および鋼材近傍のひび割れ幅がそれぞれ増加した。

図-10は簡易変位計により測定した鋼材近傍のひび割 れ幅の載荷回数による推移を示寸. 図中の直線は, 後述 の回帰式をプロットしたものである. 載荷1回と100万回 とを比較すると，鋼材近傍のひび割れ幅の増加は，かぶ り29，39，49mmの順に1.3，1.8，1.2倍となっている. 鋼 材近傍のひび割れ幅についての回帰式を求めると次のよ うになる。

$$
\begin{array}{ll}
w_{129}=0.0026 \log _{10}(N)+0.0722 & \left(R^{2}=0.78\right) \\
w_{139}=0.0049 \log _{10}(N)+0.0608 & \left(R^{2}=0.86\right) \\
w_{\text {i49 }}=0.0033 \log _{10}(N)+0.1124 & \left(R^{2}=0.50\right)
\end{array}
$$

ここに， $w_{i}$ は鋼材近傍のひび割れ幅 $(\mathrm{mm}), w_{i}$ の添え字は かぶり(mm), $N$ は載荷回数(回), $R$ は重相関係数である. なお，回帰式を求める意図は個々の実験結果から得ら れた現象同士の関係性を把握するためであり, 以後の回 帰式についても同様である.

図-11は，ひび割れに樹脂注入を行いひび割れ内部の 幅を測定した結果である。この手法は破壊測定のため, 1回と100万回の結果は異なる供試体によるものである. Husain, Fergusonの測定結果 ${ }^{4)}$ と同様，ひび割れが複数に 分岐しているとみなせる場合には，鋼材表面から同じ距 離のひび割れの幅を合計している．1回載荷の結果を見 


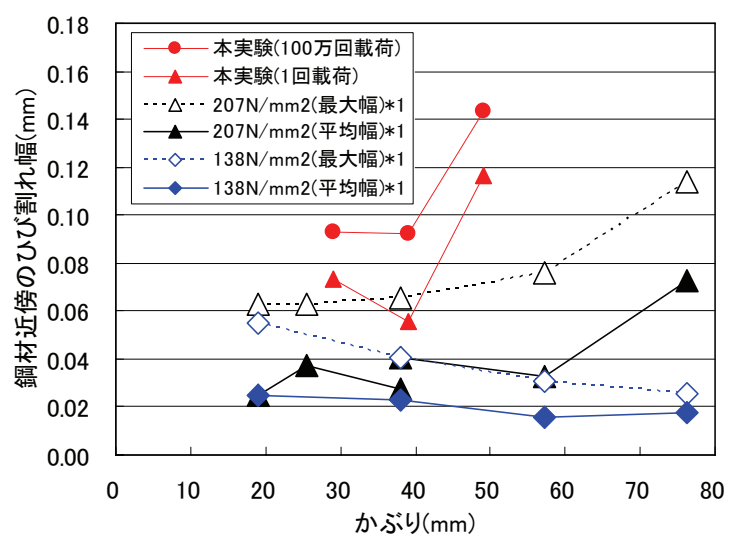

*1 Husain, Fergusonの実験結果 ${ }^{4}$

図-12 樹脂測定による鋼材近傍のひび割れ幅

ると，表面ひび割れ幅だけでなく，ひび割れ全体にわた り，かぶりの増加に応じてひび割れ内部の幅が増加して いることがわかる．樹脂注入による方法においても，か ぶり 49mmの鋼材近傍のひび割れ幅が，他に比べて大き くなっていることがわかる.

このことと同様の内容がHusain, Ferguson ${ }^{4} に$ にっても示 されている. Husain, Fergusonの研究においては，かぶり 19〜 76mm，鋼材直径19～36 mmの1段配筋，コンクリー 卜強度 $21 \sim 37 \mathrm{~N} / \mathrm{mm}^{2}$ ，供試体高さ180〜 550mm，等曲げモ ーメント区間 $2100 \mathrm{~mm}$ 梁供試体に対して，曲げ載荷に より発生した全てのひび割れに対してエポキシ樹脂を注 入し，ひび割れ内部の幅が測定されている．図-12には 本実験の測定結果とHusain, Fergusonの測定結果を併せて 示す．鋼材の上限応力度 $207 \mathrm{~N} / \mathrm{mm}^{2}$ の条件下で, かぶり が76mmになると，57mm以下の傾向とは大きく異なり鋼 材近傍のひび割れの幅が2倍程度に大きくなることが示 されている.この測定結果は，鋼材直径が本実験に比べ て大きいことや，異形鉄筋のふし形状が必ずしも同一で ないことなどにより，本実験の測定結果とは鋼材近傍の ひび割れ幅が急変するかぶりの值が異なるものの，急変 するかぶり厚さが存在するという同じ傾向を捉えている といえる.

\section{4. ひび割れ部でのコンクリートの付着剥離}

\section{(1) 実験概要}

ひび割れ部での鋼材とコンクリートとの付着が劣化す ると付着剥離部分の大きさにも影響が現れると考え，こ こでは付着剥離長さを測定することにより間接的に付着 の劣化を推定する.

主ひび割れに赤インクを注入すると，鋼材とコンクリ 一トとの隙間へ主ひび割れを通じて赤インクが進入する ため，インクの乾燥後にコンクリートを切断して鋼材を

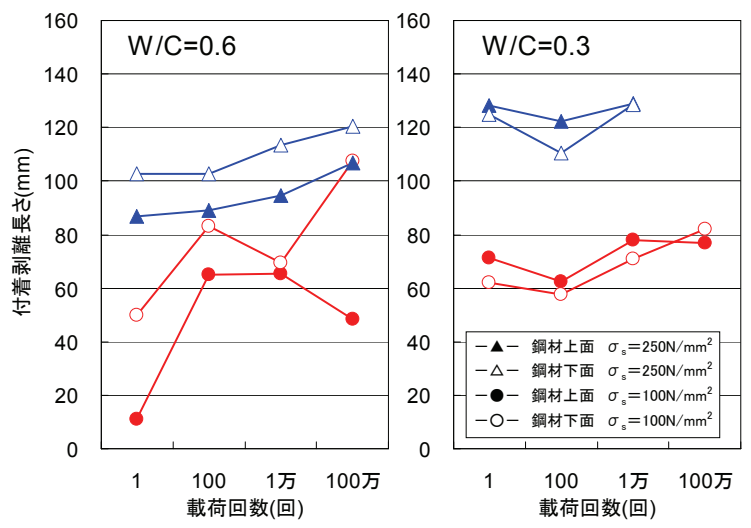

図-13 付着剥離長さ

除去すると，付着剥離した区間が赤く染まる．赤く染ま った部分の軸方向の長さを測定することで，付着剥離長 さを求めた ${ }^{8}$.

また，異形鉄筋の表面形状を一切乱さずに鋼材のひず みを連続的に測定するための供試体も別途作製した ${ }^{8}$. 供試体には，竹ふし形の異形鉄筋を縦リブに沿って半分 に切断し内側にひずみゲージを約 $17 \mathrm{~mm}$ 間隔で連続的に 貼り付けた後に接着して元の形に戻した加工鉄筋を用い た.ひずみゲージの值から求めた見掛けのヤング係数は 未加工の異形鉄筋の值とは若干異なるものの, 載荷回数 による変化を把握することが目的であるため，その影響 はないと考えている．同時に，コンクリートの表面にも 約19mm間隔で連続的にひずみゲージを貼付してひずみ を測定した。

これらの供試体では，2章ケース1と同じ両引き形状， 載荷条件とし，W/Cが2水準（0.3，0.6），鋼材応力度を2 水準 (上限応力度が $100,250 \mathrm{~N} / \mathrm{mm}^{2}$ ) とした. 実験条件 を表-1, 供試体形状を図-2に示寸。上限荷重時に載荷を 保持し，インク注入を行っている.

なお，載荷によって生じた付着剥離は，除荷時には鋼 材とコンクリートとの隙間の大きさ (距離) は弾性変形 により小さくなるものの, 短期的には剥離の状態は回復 できず，除荷時においても剥離した状態は残ると推定し ている.よって，2章ケース1での除荷後の腐食促進実験 時にも付着剥離長さは減少していないと考えている.

\section{(2) 付着剥離長さの測定結果}

ひび割れ1本あたりの付着剥離長さの平均值を図-13に 示す.この值は1本のひび割れの両側の鋼材の付着剥離 長さの和である.ブリーディングにより打設時の鋼材の 上面と下面とでは付着性状が異なるため, 付着剥離長さ を鋼材の打設時の上面と下面とで分けて整理している.

図-13を見ると，W/C=0.6においては，鋼材の下面の方 が上面よりも付着剥離長さが大きく, 平均で下面は上面 


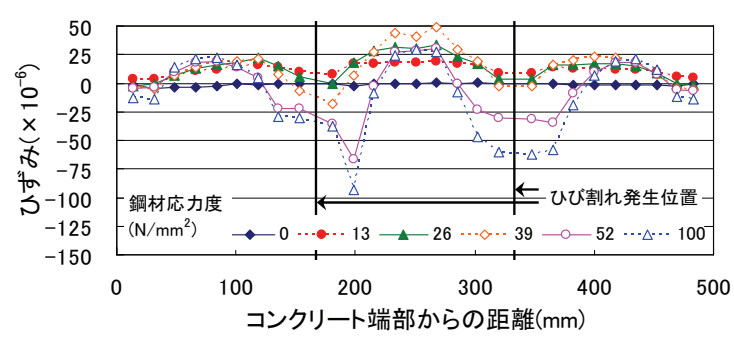

図-14 コンクリート表面のひずみ分布

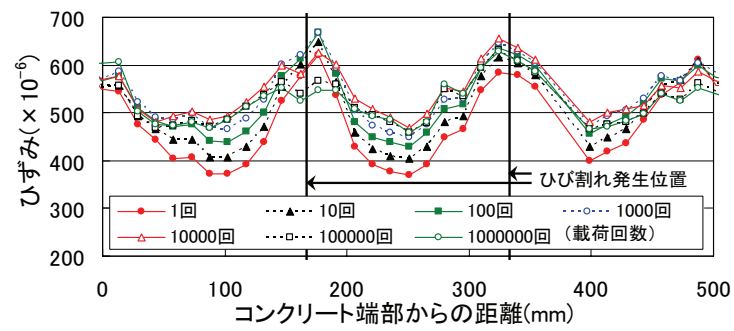

図-15 鋼材のひずみ分布

に比較して1.3倍となった。 これはブリーディングによ り鋼材下面近傍のコンクリートが脆弱になったためと考 えている．また，載荷回数が増えるにしたがい付着剥離 長さが増加する結果となり，鋼材の上下面をそれぞれ分 けて計算すると，100万回時には1回時と比較して1.2から 4.4倍に増大した。これは, 載荷回数の増加によりひび 割れ付近の付着剥離が進行することを示している．鋼材 の上限応力度が $100 \mathrm{~N} / \mathrm{mm}^{2}$ の供試体では, 1 回載荷では付 着劣化が少ないものの, 載荷の繰返しによる損傷により その後の付着劣化が進む. 一方，鋼材の上限応力度がそ れよりも高い $250 \mathrm{~N} / \mathrm{mm}^{2}$ の供試体では, 繰返しの早期に 付着が劣化するため, 繰返し数が増加してもその後の損 傷の増加が少ない.

$\mathrm{W} / \mathrm{C}=0.6$ の結果について，それぞれの上限応力度に対 して付着剥離長さの最大值（鋼材下面の值）について最 小二乗法により回帰式を求めると，次のとおりとなる.

$$
\begin{array}{ll}
L_{250}=1.39 \log _{10}(N)+100 & \left(R^{2}=0.89\right) \\
L_{100}=3.48 \log _{10}(N)+54 & \left(R^{2}=0.72\right)
\end{array}
$$

ここに，L は付着剥離長さ $(\mathrm{mm}), L$ の添え字は上限応力 度 $\left(\mathrm{N} / \mathrm{mm}^{2}\right)$ である.

式(4)と(5)の物理的な意味について，定数は初期載荷 による付着剥離の大きさを表し, 載荷回数に対する係数 は回数増加による付着剥離長さが進展する度合いを表し ている.

$\mathrm{W} / \mathrm{C}=0.3$ の場合，鋼材の上下面による差は見られない のはブリーディングが少ないためである. 繰返し数の増 加による付着剥離長さの増加の程度は, $\mathrm{W} / \mathrm{C}=0.6$ の場合
と比較すると顕著ではない．同じ鋼材応力度で比較する と, $\mathrm{W} / \mathrm{C}=0.3$ は $\mathrm{W} / \mathrm{C}=0.6$ よりも全体的に付着剥離長さが大 きくなったものの，その理由は明らかではない。 $\mathrm{W} / \mathrm{C}=0.3$ と 0.6 では鋼材に平行するコンクリート内部のイ ンク注入孔の位置を90度変えているが，その影響は無い ものと考えている.

\section{(3)ひずみ分布の載荷による変化}

ひずみゲージを内部に連続的に貼付した異形鉄筋を用 いて載荷を行った結果を示す．条件はW/C $=0.6$, 鋼材の 上限応力度 $100 \mathrm{~N} / \mathrm{mm}^{2}$ である.

載荷1回目の上限応力度 $100 \mathrm{~N} / \mathrm{mm}^{2}$ に至るまでの単調載 荷時のコンクリート表面のひずみ分布を図-14に示す. ひび割れ発生前の鋼材応力度 $\sigma_{s}=13 \mathrm{~N} / \mathrm{mm}^{2}$ 時においてはコ ンクリートのひずみ分布はほぼ一様になっているが，切 欠き部分にひび割れが発生 $\left(\sigma_{s}=26 \mathrm{~N} / \mathrm{mm}^{2}\right)$ した以後は, ひび割れ位置の近傍においてひずみが減少しており, $\sigma_{s}=52 \mathrm{~N} / \mathrm{mm}^{2}$ 以後では, 圧縮ひずみも出ている。 これは, ひび割れ部の鋼材の伸出しに伴い，鋼材付近のコンクリ ートが軸方向に引張りを受けた結果，コンクリート表面 が縮む変形を受けていることを示している.

図-15に同じ供試体における鋼材のひずみ分布の載荷 回数の増加による推移を示寸.ひび割れ近傍では鋼材ひ ずみが大きく、ひび割れ位置から離れるにつれて鋼材ひ ずみが減少している。これは既往の応力伝達の知見と一 致している. また，載荷回数が増すにつれて，全体的に 鋼材のひずみが増加している様子は，コンクリートから 鋼材一と応力の分担が推移していることを表している. これらは，ひび割れ近傍から鋼材ひずみの值が増加して いく現象でもあり, 前述の付着剥離長さが増加していく 現象を鋼材ひずみの変化から捉えているものといえる.

\section{5. 内部ひび割れと主ひび割れとの関係}

\section{(1) 実験概要}

異形鉄筋に引張力が作用すると, 鋼材の節から発生し 放射方向に発達する内部ひび割れが生じる5．内部ひび 割れは鋼材とコンクリートとの付着劣化とも密接に関わ るため, ここでは内部ひび割れの発生や進展状況の定量 評価を行う.

鉄筋コンクリートの単調載荷時の内部ひび割れの可視 化は後藤, 大塚による赤インク注入法)で既に行われて いるが，繰返し載荷後に可視化を行うためにそれとは異 なる可視化方法を著者らが考案した9). これは，予め可 視化したい面よりも数mm離した位置でコンクリートを 切断し, 真空ポンプによる脱気, インクによる空隙の置 


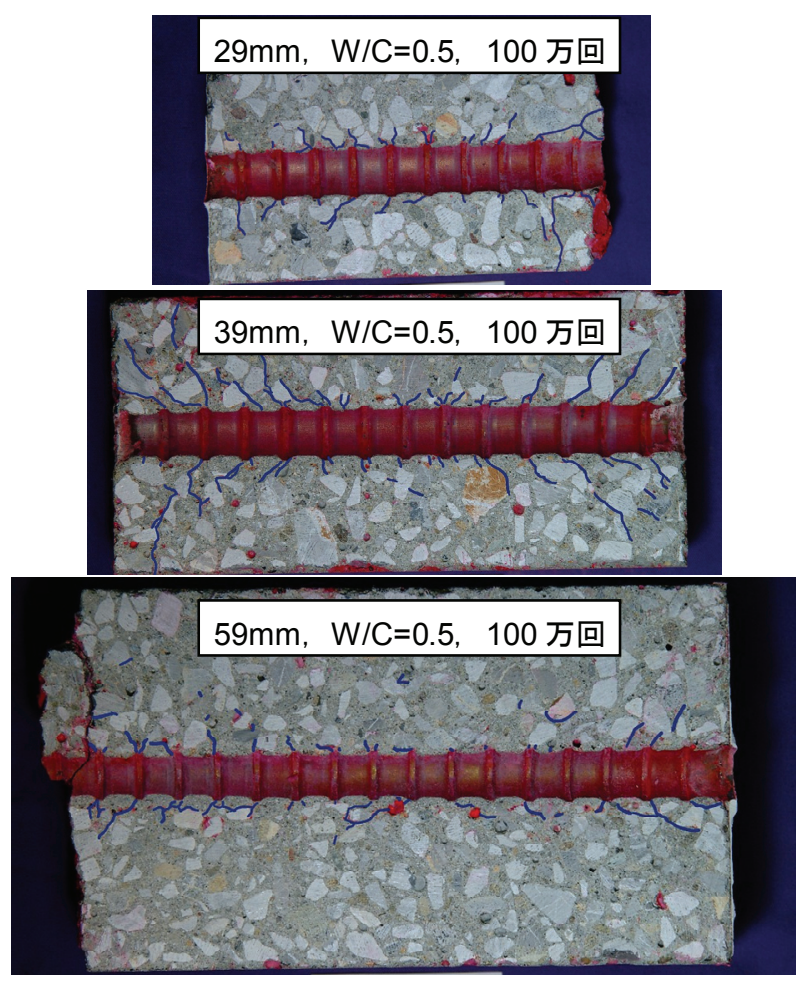

図-16 内部ひび割れの可視化結果

換，除圧の後，十分に乾燥させ，表面を研磨して可視化 面を露出する方法である。この方法を用いると，除荷に よりひび割れ幅が小さくなった場合に対しても内部ひび 割れを可視化することができる.この手法を用いると幅 0.002mm程度のひび割れに対してもインクが浸透するの を確認している.

実験要因は，載荷回数を2水準（1，100万回），W/C を2水準（0.3，0.5），かぶりを3水準（29，39，59mm） とした。実験条件を表-1，供試体形状を図-2に示寸.

\section{(2) 内部ひび割れの長さと幅}

可視化された内部ひび割れを図-16に同一縮尺で示す. これらは， $\mathrm{W} / \mathrm{C}=0.5,100$ 万回載荷後の供試体であり，供 試体の左右端が主ひび割れを表し，2本の主ひび割れに 囲まれた部分を示している。除荷により内部ひび割れの 幅が小さくなった状態であり，見や寸さのために内部ひ び割れを青色線でトレースしている.

内部ひび割れの発生状況を定量的に評価するために, 全ての内部ひび割れの長さを測定し，その総和を主ひび 割れ間隔で除して正規化したものを内部ひび割れ率とし 図-17に示寸. 載荷回数が1回の供試体同士を比較すると, $\mathrm{W} / \mathrm{C}=0.5$ の場合, かぶりが $29 \mathrm{~mm}$ と $39 \mathrm{~mm}$ では変化がなく, $59 \mathrm{~mm}$ において減少している. 載荷回数による比較では, かぶりの大きさによりばらつきがあるものの，1回から 100万回一と増えるとともに，内部ひび割れ率が増加す るものが多い.

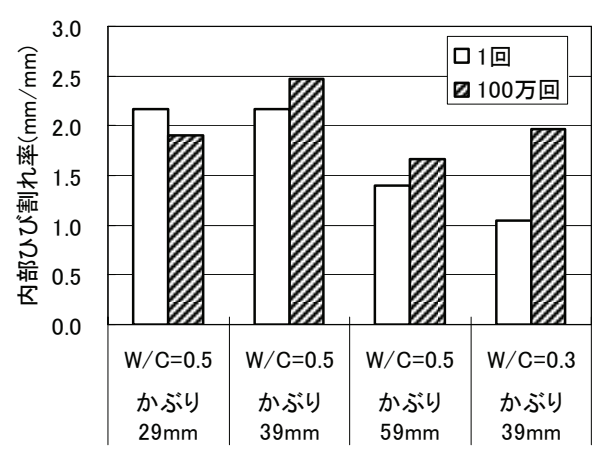

図-17 内部ひび割れ率

表-3 内部ひび割れの到達距離

\begin{tabular}{|c|c|c|c|}
\hline \multirow{2}{*}{$\mathrm{W} / \mathrm{C}$} & \multirow{2}{*}{$\begin{array}{c}\text { かぶり } \\
(\mathrm{mm})\end{array}$} & \multicolumn{2}{|c|}{$\begin{array}{c}\text { 内部ひび割れ } \\
\text { の到達距離 } \\
(\mathrm{mm})\end{array}$} \\
\cline { 3 - 4 } & & 1回 & 100 万回 \\
\hline \multirow{3}{*}{0.5} & 29 & 29 & 29 \\
\cline { 2 - 4 } & 39 & 39 & 39 \\
\cline { 2 - 4 } & 59 & 16 & 30 \\
\hline 0.3 & 39 & 39 & 39 \\
\hline
\end{tabular}

発生した内部ひび割れのうち鋼材表面から一番遠くま で到達したひび割れに対して，鋼材表面からひび割れ先 端までの最短距離を内部ひび割れの到達距離と定義し, 表-3に示す．表-3および図-16に示すとおり，かぶり 29mm，39mmともに，発生した内部ひび割れは，その一 部が主ひび割れ（図の左右端）に繋がったり，コンクリ 一ト表面（図の上下端）に達している。一方，かぶり 59mmについては，全体的に内部ひび割れがコンクリー ト表面に到達するものはなかった.

除荷後の鋼材近傍における内部ひひ割れの幅をマイク ロスコープにより測定した結果, 載荷回数による大きな 違いは見られなかった9)。この理由については, 除荷に より内部ひび割れの幅が小さく変化したためなのか, 載 荷時においても内部ひび割れの幅には変化がなかったた めなのか，本手法では確認することができない.

\section{(3) かぶりの増加と内部ひび割れ ·主ひび割れとの関係}

主ひび割れ幅とは，引張を受ける鋼材のひずみ増加に 対して，コンクリートの見掛けの伸び能力が追従できな い部分の長さと考えることができる. 見掛けの伸び能力 とは, 内部ひび割れも含んだコンクリートの変形能力で ある.

かぶりが小さい条件（今回はかぶり $29 \mathrm{~mm}$ と $39 \mathrm{~mm}$ ) で は異形鉄筋の節から発生した内部ひび割れは主ひび割れ 近傍ではコンクリート表面へ到達し，主ひび割れ近傍の コンクリートにも多くの内部ひび割れが生じている，そ の結果として主ひび割れ1本の幅が小さく抑えられてい 
ることが推察できる，反対にかぶりが大きい条件（同 59mm）では，鋼材から遠いコンクリート表面付近には 内部ひび割れが到達していない.この理由は，内部ひび 割れは放射方向に進展するが，鋼材から離れるにしたが い健全なコンクリートの体積が増し拘束体のように寄与 するためであると考えている. よって内部ひび割れの長 さや本数が少なく見掛けのコンクリートの変形能力が小 さくなり，その結果主ひび割れの幅が大きくなると推察 している.

これらの挙動の違いの境目になるかぶりの值は，コン クリートの強度，鋼材の直径，節の高さ，鉄筋比にも影 響を受けることが考えられるため一概にはいえないもの の, 図-12のとおり, 本研究の範囲においては3章の両引 き供試体では49mm, Husain, Ferguson ${ }^{4}$ の研究の梁供試体 においては76mmであり，それよりかぶりが小さい供試 体に比べて鋼材近傍のひび割れ幅が急激に大きくなる.

以上は観察された結果から組み立てた仮説であり，ひ び割れ発生のメカニズムとして今後さらに検討する必要 がある。

\section{(4)内部ひび割れと他の現象との関係}

内部ひび割れの発生は鋼材とコンクリートとの付着が 緩む現象と対応しているため, 内部ひび割れの発生や進 展は，主ひび割れ部における鋼材の伸出しと対応してい ると考えている.よって, 主ひび割れ部における鋼材近 傍のひび割れ幅が大きくなることや，付着剥離長さが大 きくなることの原因の1つとして，内部ひび割れの発生 を挙げることができる.

本研究では，主ひび割れ部での物質移動を主として想 定したコンクリート構造物の耐久性を検討している. か ぶりが小さい場合，主ひび割れ近傍のコンクリート自体 も内部ひび割れにより損傷を受けているため，たとえひ び割れ幅が小さくてもかぶりの物質移動抵抗性の低下も 同時に起こっているといえよう，どちらによる影響が卓 越するかについては，今後さらに検討が必要である。本 研究では対象外としているが, 氏家ら ${ }^{17,18}$ により単調お よび繰返し荷重が作用した場合，鉄筋コンクリート供試 体の主ひび割れを含まない部分のコンクリートの透気性 および塩分浸透性が増加することが実験的に確かめられ おり，これらは内部ひび割れによるものと考察されてい る.内部ひび割れが直接的にも物質移動抵抗性に影響を 与えている一例である.

\section{6. ひび割れの内部損傷が鋼材腐食に与える影響}

これまでに実験的に求めた付着剥離長さおよび鋼材近
傍のひび割れ幅について，鋼材腐食との関係を整理する. 鋼材近傍のひび割れ幅が増加すると物質移動が促進され， 付着剥離長さが増加すると腐食が発生しうる部分の面積 が増加するため腐食発生の確率が増加することが考えら れるため，ともに腐食開始が早くなることが推察できる。 この関係を実験結果から導いた式を用いて示す. 載荷の 繰返しが増加するにしたがい，付着剥離長さの進展と鋼 材近傍のひび割れ幅の増加は同時に起こっているため, 今回は付着剥離長さのみを取り上げる.

腐食促進実験については，ひび割れ内部まで乾燥と湿 潤が繰り返される2章ケース2の梁供試体の実験を取り上 げる．腐食促進実験と付着剥離長さ測定で共通している かぶりの大きさ約 $40 \mathrm{~mm}$ （実験ではそれぞれ40mmと 39mm）の場合について考える. 図-7においてかぶり 40mmの供試体では，1回載荷では5日（1サイクル）， 100万回載荷では15日（3サイクル）で鋼材腐食が開始し た. 途中の載荷回数についても載荷回数の対数に比例し て腐食開始日数が決まると仮定すると, $\mathrm{W} / \mathrm{C}=0.5$, かぶ り $40 \mathrm{~mm}$ ，上限灾力度 $180 \mathrm{~N} / \mathrm{mm}^{2}$ の条件において，任意の 載荷回数後の腐食開始日数は式(6)で表される.

$$
D_{N}=-0.723 \log _{10}(N)+15
$$

ここに， $D_{N}$ は載荷回数 $N$ 回における鋼材の腐食開始日 数(日)である.

付着剥離長さについては，ここでは簡単のため鋼材の 応力振幅は考えず上限応力度のみに比例すると仮定する と, $\mathrm{W} / \mathrm{C}=0.6$ のときには，式(4), 式(5)を単純に上限応力 度で比例配分すると, 任意の上限応力度 $\sigma_{s}$ の付着剥離長 さは式(7)で表される.

$$
L_{\sigma_{s}}=\frac{\left(250-\sigma_{\mathrm{s}}\right) L_{100}+\left(\sigma_{\mathrm{s}}-100\right) L_{250}}{150}
$$

ここに， $\sigma_{s}$ は鋼材の上限応力度 $\left(\mathrm{N} / \mathrm{mm}^{2}\right)$ である.ただし， $100 \leqq \sigma_{s} \leqq 250$ とする.

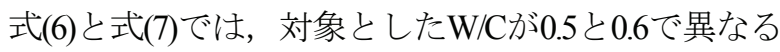
ものの，ひび割れを通る物質移動が律速の状態を考える と，その違いはないものとここでは仮定する．繰返し荷 重の上限応力度が $180 \mathrm{~N} / \mathrm{mm}^{2}$ のときには，式(7)に $\sigma_{s}=180 を$ 代入したものと式(6)とを組み合わせると, 腐食開始日 数と付着剥離長さの間に式(8)の関係が得られる.

$$
D_{N}=-0.305 L_{180}+38.9
$$

式(8)の関係については，かぶり約 $40 \mathrm{~mm}$ ，本実験にお ける腐食促進実験条件下で得られたものである。その範 
囲内では，式(8)は付着剥離長さが大きくなるにしたが い腐食開始日数が小さくなることを示している．実環境 下においては腐食促進実験の縮小スケールが不明確のた め，このまま適用できるかについてはさらなる検討が必 要である.

\section{7. 結論}

ひび割れの内部構造に着目して鋼材腐食を検討した 本研究において, W/Cが0.3から0.6, かぶりが $29 \mathrm{~mm}$ から $59 \mathrm{~mm}$, 繰返し載荷回数が 100 万回までの範囲の実験条件 で得られた知見を以下に取りまとめる.

1)ひび割れ部での物質移動が支配的となる比較的短期の 状態において，載荷回数が増えると，塩化物による鋼 材腐食の開始が早まる．その理由として，載荷の繰返 しにより，コンクリートの鋼材近傍のひび割れ幅が 1.2 から1.8倍の範囲で増加すること，鋼材とコンクリート との付着剥離長さが1.2から 4.4 倍の範囲で増大すること を示した。

2)かぶりが大きくなると，主ひび割れ内部の幅がかぶり が小さいものに比べて急激に大きくなる場合がある. その理由の1つが，内部ひび割れの発生状況の違いに よるものであることを示した.

3) 樹脂注入法や変位計を使ってひび割れ内部の幅を測定 した結果から，載荷回数が増えるとひび割れ内部の幅 も増加する。

4)インク注入法を用いた可視化の結果から，主ひび割れ 近傍に生じる鋼材とコンクリートとの付着剥離長さは, 鋼材応力度の増加, 載荷回数の増加にしたがい増加す る.また，コンクリート打設時の鋼材の上下面の付着 剥離長さを比較すると, ブリーディングにより鋼材下 面の方が付着剥離長さが大きい.

5) 異形鉄筋の付着を乱さずに測定した鋼材ひずみおよび コンクリートひずみの測定結果から, 鋼材応力度の増 加や載荷回数の増加により付着劣化が進行し，コンク リートから鋼材へと応力分担が推移する.

6) 繰返し載荷後にも適用できるひび割れの可視化手法を 用いて内部ひび割れの長さを測定した結果から，繰返 し載荷の増加により内部ひび割れ率が増加する.

謝辞 : 本研究の実施にあたり，横浜国立大学コンクリー 卜研究室の森竹巧, 高梨大介, 五十嵐悠, 白川裕之, 萩 原和樹，吉田佳代，米田雄治の諸氏には大変お世話にな った. 本研究の一部には, 平成18，19年度文部科学省科 学研究費補助金（若手研究（B）, 課題番号 18760347 ,
研究代表者 : 林 和彦) および土木学会平成19年度吉田 研究奨励賞の助成を受けた. エポキシ樹脂注入に際して はアルファ工業株式会社からの助言と材料提供を受けた。 ここに記して謝意を表す。

\section{参考文献}

1) 土木学会 : コンクリート標準示方書設計編, 2007.

2) 今本啓一: ひび割れと各種性能, 鉄筋コンクリート造建築物 の収縮ひび割れ制御設計・施工指針(案) ・同解説，日本建築 学会, pp.223-233, 2006.

3) 神山一 : コンクリート中の鉄筋のさび, セメント・コンクリ 一ト, No.308, pp.50-57, 1972.

4) Husain, S. I. and Ferguson, P. M.: Flexural Crack Width at the Bars in Reinforced Concrete Beams, Research Report Number 102-1F, Center for Highway Research, the University of Texas at Austin, 1968.

5) 後藤幸正, 大塚浩司 : 引張を受ける異形鉄筋周辺のコンクリ 一トに発生するひび割れに関する実験的研究，土木学会論 文報告集，第294号，pp.85-100，1980.

6) 五十嵐悠，林和彦，椿龍哉 : 繰返し載荷を受けたRC部材の 鋼材腐食に及ぼす影響要因, 土木学会第62回年次学術講演会 講演概要集, 5-485, pp.969-970, 2007.

7) 吉田佳代, 米田雄治, 林和彦, 椿龍哉 : 繰返し載荷によるひ び割れ形状の変化がRC部材の鋼材腐食に及ぼす影響, 第63 回セメント技術大会講演要旨, pp.134-135, 2009.

8) 林和彦, 高梨大介, 五十嵐悠, 椿龍哉 : 繰返し荷重を受ける $\mathrm{RC}$ 部材の異形鉄筋周辺のひび割れ性状，コンクリート工学 年次論文集，Vol.29，No.3，pp.619-624， 2007.

9) 白川裕之, 林和彦, 細田暁, 椿龍哉 : 繰返し荷重を受けた $\mathrm{RC}$ 部材における鋼材腐食と内部損傷に関寸る実験的研究, コンクリート工学年次論文集, Vol.30, pp.765-770， 2008.

10) 林和彦, 椿龍哉, 森竹巧 : 疲労荷重を受けるRC部材のひび 割れ成長，コンクリート工学年次論文集，Vol.27，pp.877-892， 2005.

11) 林和彦，椿龍哉，高梨大介 : 繰返し荷重を受けるRCはりの ひび割れ幅，土木学会第61回年次学術講演会 講演概要集，5566, pp.1127-1128, 2006.

12) 土木学会 : 土木学会コンクリート標準示方書に基づく設計 計算例 [鉄道構造物編］，コンクリートライブラリー 118 , 2005.

13) 日本道路協会 : 道路橋示方書・同解説 III コンクリート橋 編, 2002.

14) 土木学会規準 : コンクリート構造部における自然電位測定 方法(案), JSCE-E 601-2007, 2007.

15) 土木学会 : 鉄筋腐食・防食および補修に関する研究の現状 と今後の動向，コンクリート技術シリーズ26，p.123，1997.

16) 角田与史雄 : 鉄筋コンクリートの最大ひびわれ幅, コンク リート・ジャーナル, Vol.8, No.9, pp.1-10, 1970.

17) 氏家勲, 佐藤良一, 長瀧重義 : 内部ひび割れに起因するか ぶりコンクリートの密実性低下の透気性による検討，土木 学会論文集, No.550/V-33, pp.163-172, 1996.

18) 氏家勲，小林清和，佐藤良一，長瀧重義 : 内部ひび割れを 有するかぶりコンクリートの塩分浸透性に関する研究，コ ンクリート工学年次論文報告集，Vol.14，No.1，pp.843-848， 1992.

(2009.4.8 受付) 


\section{INFLUENCE OF INTERNAL STRUCTURE OF FLEXURAL CRACK ON STEEL CORROSION OF REINFORCED CONCRETE MEMBERS}

\section{Kazuhiko HAYASHI, Tatsuya TSUBAKI and Akira HOSODA}

Flexural cracks adversely affect mass transfer in cover concrete of reinforced concrete members. However, the internal structure of flexural cracks including crack width near a reinforcing bar and bond degradation area has not been figured out sufficiently except for surface crack width. The effects of internal structure of flexural cracks on mass transfer and on corrosion of reinforcing bars have not also been clarified. It is also unclear whether increasing cover thickness to improve durability affects the internal structure of flexural cracks or not.

In this research, focusing on cyclic loading and cover thickness, the effects of internal structure of flexural cracks on steel corrosion were examined by accelerated corrosion tests and visualization of cracks.

As results, it became clarified that the crack width near reinforcing bar and bond degradation area were increased and the initiation of steel corrosion was made earlier by increasing the number of cyclic loading, and that the crack width near reinforcing bar was increased in some cases with the increase of cover thickness due to the localization of damages around a reinforcing bar near the main crack. 